\title{
Involvement of insulin-degrading enzyme in the clearance of beta-amyloid at the blood-CSF barrier: Consequences of lead exposure
}

\author{
Mamta Behl, Yanshu Zhang and Wei Zheng*
}

Address: School of Health Sciences, Purdue University, West Lafayette, IN 47907, USA

Email: Mamta Behl - mbehl@purdue.edu; Yanshu Zhang - zhang78@purdue.edu; Wei Zheng* - wzheng@purdue.edu

* Corresponding author

Published: II September 2009

Cerebrospinal Fluid Research 2009, 6:II doi:I0.1 I86/I743-8454-6-II
Received: 29 June 2009

Accepted: II September 2009

This article is available from: http://www.cerebrospinalfluidresearch.com/content/6/I/I I

(c) 2009 Behl et al; licensee BioMed Central Ltd.

This is an Open Access article distributed under the terms of the Creative Commons Attribution License (http://creativecommons.org/licenses/by/2.0), which permits unrestricted use, distribution, and reproduction in any medium, provided the original work is properly cited.

\begin{abstract}
Background: Alzheimer's disease $(A D)$ is characterized by the deposition of beta-amyloid $(A \beta)$ peptides in the brain extracellular matrix, resulting in pathological changes and neurobehavioral deficits. Previous work from this laboratory demonstrated that the choroid plexus (CP) possesses the capacity to remove $A \beta$ from the cerebrospinal fluid (CSF), and exposure to lead $(\mathrm{Pb})$ compromises this function. Since metalloendopeptidase insulin-degrading enzyme (IDE), has been implicated in the metabolism of $A \beta$, we sought to investigate whether accumulation of $A \beta$ following $\mathrm{Pb}$ exposure was due to the effect of $\mathrm{Pb}$ on IDE.
\end{abstract}

Methods: Rats were injected with a single dose of $\mathrm{Pb}$ acetate or an equivalent concentration of $\mathrm{Na}$-acetate; $\mathrm{CP}$ tissues were processed to detect the location of IDE by immunohistochemistry. For in vitro studies, choroidal epithelial Z3 I 0 cells were treated with $\mathrm{Pb}$ for $24 \mathrm{~h}$ in the presence or absence of a known IDE inhibitor, $\mathrm{N}$-ethylmaleimide (NEM) to assess IDE enzymatic activity and subsequent metabolic clearance of $A \beta$. Additionally, the expression of IDE mRNA and protein were determined using real time PCR and western blots respectively.

Results: Immunohistochemistry and confocal imaging revealed the presence of IDE towards the apical surface of the $\mathrm{CP}$ tissue with no visible alteration in either its intensity or location following $\mathrm{Pb}$ exposure. There was no significant difference in the expressions of either IDE mRNA or protein following $\mathrm{Pb}$ exposure compared to controls either in $\mathrm{CP}$ tissues or in $\mathrm{Z} 3 \mathrm{I} 0$ cells. However, our findings revealed a significant decrease in the IDE activity following $\mathrm{Pb}$ exposure; this inhibition was similar to that seen in the cells treated with NEM alone. Interestingly, treatment with Pb or NEM alone significantly increased the levels of intracellular $A \beta$, and a greater accumulation of $A \beta$ was seen when the cells were exposed to a combination of both.

Conclusion: These data suggest that $\mathrm{Pb}$ exposure inhibits IDE activity but does not affect its expression in the CP. This, in turn, leads to a disrupted metabolism of $A \beta$ resulting in its accumulation at the blood-CSF barrier. 


\section{Background}

Studies in literature have shown that more than $90 \%$ of Alzheimer's disease (AD) cases are sporadic in nature [1], suggesting the involvement of environmental triggers in addition to genetic mutations. Amongst occupational and environmental factors, exposure to toxic metal lead $(\mathrm{Pb})$ has been associated with severe memory deficits and ADlike pathology as indicated by studies on Pb-exposed workers [2,3]. The deleterious effects of $\mathrm{Pb}$ were documented as early as in 1975, when a patient who survived severe $\mathrm{Pb}$ encephalopathy at 2 years of age, died of severe mental deterioration at the age of 42 ; neurofibrillary tangles and senile plaques, two hallmarks of AD pathology, were detected in his forebrain with significant hippocampal degeneration [4]. Other evidence linking Pb exposure and memory deficits stems from recent studies conducted on cohorts of workers who have been occupationally exposed to $\mathrm{Pb}$. When their brains were examined by magnetic resonance imaging (MRI), extensive brain atrophy was seen in the cortical, hippocampal and ventricular regions that is typical of $\mathrm{AD}$ patients. The brain atrophy and neurobehavioral deficits in these workers appeared to persist several years post $\mathrm{Pb}$ exposure and correlate with a high tibia $\mathrm{Pb}$ concentration, a marker often used to estimate cumulative $\mathrm{Pb}$ exposure [2,3,5-7]. In animal models, developmental exposure to $\mathrm{Pb}$ has been associated with an early transient and delayed over-expression of amyloid precursor protein (APP) and its amyloidogenic product, $\beta$-amyloid $(A \beta)$ [8]. These studies and others [9,10], provide evidence to support a linkage between $\mathrm{Pb}$ exposure and the pathogenesis of AD.

One of the target regions in the brain where $\mathrm{Pb}$ has shown to accumulate substantially is the choroid plexus (CP), a tissue lining the brain ventricles and separating the blood from the CSF. This finding is supported by evidence from an autopsy study which showed an age-related accumulation of $\mathrm{Pb}$ in the CP of the brains of 51 human subjects who had lived in New York City [11]. This observation was later confirmed by another independent human autopsy study revealing a 100 -fold increase of $\mathrm{Pb}$ in the CP compared with the brain cortex [12]. These findings were corroborated by studies in rodents demonstrating a dose-dependent and time-related accumulation of $\mathrm{Pb}$ in the CP at concentrations 57 and 70 fold greater than the brain cortex and CSF, respectively $[13,14]$.

Recent studies from this laboratory have demonstrated that $\mathrm{Pb}$ accumulation in the $\mathrm{CP}$ results in a marked increase of $A \beta$ within the tissue [15]. Since the CP plays a significant role in $A \beta$ transport and clearance from the CSF [16], the objective of this study was to investigate the mechanism by which $\mathrm{Pb}$ interferes with the metabolic clearance of $A \beta$, specifically its degradation by insulindegrading enzyme (IDE).
IDE, a 110-KD zinc metallopeptidase, is known to participate extensively in the clearance of insulin, glucagon and A $\beta$ [17-21]. The common physicochemical characteristics shared by IDE substrates include hydrophobicity and the substrate's ability to aggregate readily to form fibrils $[18,22,23]$. IDE is known to be present in the cytosol, peroxisomes as well as in the mitochondria of neuronal and non-neuronal cells in the brain [24-26]. It has also been detected in the human CSF of both normal and Alzheimer subjects [20,21,27]. Noticeably, a decrease in IDE has been associated with impaired neuronal regulation of $A \beta$ as well as deficits in spatial memory in both rats and AD patients [28-31]. Other studies involving genetic deletions of IDE in mice have shown a significant elevation in both, brain $A \beta$ and plasma insulin [25,32]. Interestingly, an upregulation of IDE in neurons has been shown to prevent against AD-like pathology in transgenic mice which overexpress APP [25,33]. Recently, IDE has been identified in the CP by our group, although its exact role in $\mathrm{A} \beta$ metabolic clearance remains unclear [34].

Considering the substantial accumulation of $\mathrm{Pb}$ and the abundant presence of IDE in the CP, there was sound reason to hypothesize that accumulation of $\mathrm{Pb}$ may alter the enzymatic activity or expression levels of IDE in the CP, leading to alterations in $A \beta$ metabolism at the blood-CSF barrier (BCB). Thus, the purpose of this study was to (1) identify the subcellular location of IDE in the CP, (2) determine whether $\mathrm{Pb}$ exposure in vivo affected the subcellular distribution of IDE, (3) investigate whether Pb exposure altered the IDE activity and/or the expression of mRNA or protein levels in the CP, and (4) determine whether altered IDE function led to the abnormal accumulation of $\mathrm{A} \beta$ in the $\mathrm{BCB}$. The outcomes of this study will establish the role of IDE in the metabolic clearance of $\mathrm{A} \beta$ at the $\mathrm{BCB}$ and illustrate a mechanism by which $\mathrm{Pb}$ alters $\mathrm{A} \beta$ homeostasis in the CSF, potentially contributing to the etiology of AD.

\section{Methods \\ Materials}

Chemicals and assay kits were purchased as follows: ELISA kit and ultra purified A $\beta$ (1-40) (\#KHB-3841 and \#03-136, Biosource, Carlsbad, USA); mouse anti -IDE antibody (\#MMS 282R, Covance Inc, Princeton, USA); IDE activity kit (\# CBA079, Calbiochem Gibbstown, USA); Alexa-labeled secondary anti- mouse antibody (Molecular Probes, Eugene, USA); enhanced chemiluminescene reagent (ECL) and ECL films (Amersham Biosciences, Piscataway, USA); Dulbecco's modified essential medium (DMEM), fetal bovine serum (FBS), penicillin, streptomycin, and gentamycin (Gibco, Grand Island, USA); PCR buffer, dNTP, Oligo dT and MuLV reverse transcriptase (Applied Biosystems, Foster City, USA); the ABsolute QPCR SYBR green Mix kit (ABgene, Rochester, 
USA); the primers for real time RT-PCR (Integrated DNA Technology Inc., Coralville, USA); $\beta$-actin, 2 -mercaptoethanol, phenylmethylsulfonyl fluoride (PMSF), polyacrylamide, tetramethyl-ethylenediamine (TEMED), nethylmaeimide (NEM) and all other chemicals (Sigma Chemicals, St. Louis, USA). All reagents were of analytical grade, HPLC grade or the best available pharmaceutical grade.

\section{Animals and treatment}

Male Sprague-Dawley rats were purchased from Harlan Laboratories (Indianapolis, USA) and were 8-9 weeks old (250-300 g) at the time they were used. The animals were housed in a temperature-controlled, $12 \mathrm{~h}: 12 \mathrm{~h}$ light/dark room, and were allowed free access to tap water and food. Rats received an i.p. injection of $50 \mathrm{mg} / \mathrm{kg} \mathrm{Pb}$ acetate (i.e., $27 \mathrm{mg} \mathrm{Pb} / \mathrm{kg}$ ) or an equivalent molar concentration of $\mathrm{Na}-$ acetate (i.e., $15 \mathrm{mg}$ acetate $/ \mathrm{kg}$ ) as control. Twenty-four $\mathrm{h}$ post injection, the rats were anesthetized with an injection of ketamine/xylazine $(75: 10 \mathrm{mg} / \mathrm{mL}, 1 \mathrm{~mL} / \mathrm{kg}$ body weight) and euthanized by exsanguination to remove excess blood. The lateral ventricle CP was then isolated for further experimentation. Animal protocols pertinent to this study were approved by the Purdue University Animal Care and Use Committee.

\section{Culture of choroidal epithelial Z3 IO cells}

The methods and characteristics of immortalized rat choroidal epithelial Z310 cells have been described previously [35]. Briefly, cells were maintained in DMEM (high glucose) medium supplemented with $10 \%$ FBS, $100 \mathrm{U} /$ $\mathrm{mL}$ penicillin, $100 \mu \mathrm{g} / \mathrm{mL}$ streptomycin, and $40 \mu \mathrm{g} / \mathrm{mL}$ of gentamycin in a humidified incubator with 95\% air-5\% $\mathrm{CO}_{2}$ at $37^{\circ} \mathrm{C}$ and were passaged twice a week. The cells were seeded at a density of $1 \times 10^{6}$ in a $100-\mathrm{mm}$ culture dish. Twenty-four $\mathrm{h}$ after initial seeding, the cells were treated with 0 or $10 \mu \mathrm{M} \mathrm{Pb}$ for 24 or $48 \mathrm{~h}$, and the following studies were performed.

\section{Immunohistochemistry}

Immunohistochemistry was performed on both rat $\mathrm{CP}$ tissues and the Z310 cells following Pb exposure. For fresh tissue studies, the CPs were isolated from the rat following the exposure condition described above and transferred to a 35-mm glass bottomed dish containing PBS. For in vitro studies, Z310 cells were seeded on a 35-mm dish, and treated with $10 \mu \mathrm{M} \mathrm{Pb}$ for 24 or $48 \mathrm{~h}$. At the end of $\mathrm{Pb}$ treatment, the culture medium was removed and replaced with $0.5-1 \mathrm{~mL}$ PBS. The tissues or cells were washed with PBS three times, fixed with 3\% paraformaldehyde $/ 0.25 \%$ glutaraldehyde in PBS for $10 \mathrm{~min}$, and permeabilized with $0.5 \%$ Triton X-100 for $30 \mathrm{~min}$ at room temperature, followed by 3-5 washes of PBS. After blocking with $1 \%$ bovine serum albumin (BSA) in PBS for $30 \mathrm{~min}$ at room temperature, the tissues or cells were double-immunos- tained with mouse anti-IDE (1:500) in 1\% BSA overnight at $4{ }^{\circ} \mathrm{C}$, washed the next day with PBS in $1 \%$ BSA, and then incubated with goat anti- mouse Alexa- 488 conjugated secondary antibody $(1: 7500)$ in $1 \%$ BSA at $37^{\circ} \mathrm{C}$ for 60 $\mathrm{min}$. After further washing in PBS with 1\% BSA, the tissues or cells were observed using an inverted confocal fluorescent microscope. Negative controls were treated similarly except that they were not exposed to any of the primary antibodies.

\section{Confocal immunofluorescence microscopy}

To acquire images, the dish containing the CP specimen was mounted on the stage of an Olympus, FV1000 inverted confocal laser-scanning microscope and viewed through a $40 \times$ water-immersion objective (numeric aperture $=1.2$ ), with a 488-nm laser line for excitation (Ar-ion laser). Low laser intensity was used to avoid photo bleaching. The CP was examined under a reduced transmittedlight illumination. An area containing undamaged epithelium with underlying vasculature was selected. For each image acquired (512 $\times 512 \times 8$ bits, 4 frames averaged), four areas of the specimen were selected for image collection. Data reported, unless otherwise stated, are representative of 3-4 replicate experiments.

\section{Assay of IDE enzymatic activity}

To screen for a suitable NEM concentration at which cell death was minimal, $\mathrm{Z} 310$ cells were seeded at a density of $1 \times 10^{6}$ in $100-\mathrm{mm}$ plates for $24 \mathrm{~h}$; they were then incubated with $0,5,10,25$ or $50 \mu \mathrm{M}$ of NEM overnight for 16 $\mathrm{h}$ and the cell viability was determined using the methylthiazolyldiphenyl-tetrazolium bromide (MTT) assay. Based on our results and previously published data [21], a concentration of $10 \mu \mathrm{M}$ NEM was selected as an appropriate concentration for the IDE activity experiments described below.

To assess the IDE activity, the cells were seeded at a density of $1 \times 10^{6}$ and treated with $\mathrm{Pb}$ for 24 or $48 \mathrm{~h}$ in the presence or absence of NEM. The four treatment conditions were as follows: Group 1 served as an untreated control (Pb-/NEM-), group 2 was treated with $10 \mu \mathrm{M} \mathrm{Pb}$ for $24 \mathrm{~h}$ in the absence of NEM ( $\mathrm{Pb}+/ \mathrm{NEM}-)$, group 3 was treated with only $10 \mu \mathrm{M}$ NEM for $16 \mathrm{~h}$ in the absence of Pb (Pb-/ $\mathrm{NEM}+$ ), and group 4 with $10 \mu \mathrm{M}$ NEM for $16 \mathrm{~h}$ followed by $10 \mu \mathrm{M} \mathrm{Pb}$ for $24 \mathrm{~h}(\mathrm{~Pb}+/ \mathrm{NEM}+)$.

The principle of the assay is based on measuring the IDE activity using a fluorescence resonance energy transfer (FRET) substrate which is cleaved by IDE to release the fluorophore from the quenching molecule, resulting in an increase in fluorescence. The activity was determined as per manufacturer's protocol (Calbiochem, catalog \# CBA079). Briefly, Z310 cells were lysed with RIPA buffer and centrifuged at 10,000 rpm for $10 \mathrm{~min}$ and the super- 
natant was used for analysis. Total protein $(80 \mu \mathrm{g} /$ well $)$ was loaded into in a 96-well plate, which contained an affinity-purified polyclonal antibody that recognizes human, mouse, and rat insulysin; the antibody was immobilized on the plate in order to capture the IDE enzyme. Following $1 \mathrm{~h}$ incubation, the plate was washed with sample buffer, and an aliquot $(100 \mu \mathrm{L})$ of substrate was added and incubated for $2-4 \mathrm{~h}$ at $37^{\circ} \mathrm{C}$ in the dark. The fluorescence was measured using an excitation wavelength of $320 \mathrm{~nm}$ and an emission wavelength of $405 \mathrm{~nm}$. The results are reported as IDE fluorescence intensity in arbitrary units (a.u.)/mg of total proteins in the cells.

\section{Quantification of $A \beta_{1-40}$ accumulation in $Z 310$ cells following $\mathrm{Pb}$ exposure by ELISA}

Cells were grown on 24 well plates at a density of $\sim 4 \times 10^{4}$ cells/well and treated as the four groups described above. The cells were washed with PBS and incubated with 200 $\mu \mathrm{L}$ of $2 \mu \mathrm{M}$ ultrapure $\mathrm{A} \beta_{1-40}$ solution in serum free medium for $1 \mathrm{~h}$. The medium was then removed, cells washed 3 times with PBS, and fresh serum-free medium added for an additional hour to allow for metabolic clearance of $A \beta$ by IDE. The cells were then washed with PBS, scraped and lysed using $60 \mu \mathrm{L}$ of RIPA buffer. The intracellular $\mathrm{A} \beta$ was determined using a colorimetric ELISA kit (Invitrogen KHB3481). All data reported from the ELISA were normalized to the total amount of protein in the cells as determined by the Bradford assay.

\section{Quantification of IDE mRNA expression by real-time (RT)- PCR}

The transcription of the gene encoding IDE was quantified using RT-PCR as described in [36]. Briefly, the total RNA was isolated from Z310 cells or plexus tissue using TRIzol reagent, following the manufacturer's instructions. An aliquot of RNA ( $1 \mu \mathrm{g})$ was reverse-transcribed with MuLV reverse-transcriptase and oligo $\mathrm{dT}$ primers. The forward and reverse primers for target genes were designed using Primer Express 3.0 software. The ABsolute QPCR SYBR green (Mix kit, ABgene) was used for RT-PCR analyses. The amplification was carried out in the MX 3000P realtime PCR System (Stratagene, La Jolla, USA). Amplification conditions were $15 \mathrm{~min}$ at $95^{\circ} \mathrm{C}$, followed by 40 cycles of $30 \mathrm{~s}$ at $95^{\circ} \mathrm{C}, 1 \mathrm{~min}$ at $55^{\circ} \mathrm{C}$ and $30 \mathrm{~s}$ at $72^{\circ} \mathrm{C}$. A dissociation curve was used to verify that the majority of fluorescence detected could be attributed to the labeling of specific PCR products, and to verify the absence of primer-dimers and sample contamination. All RT-PCR reactions were done in triplicate. Primer sequences for rat IDE used for real-time RT-PCR were: forward primer 5' GGTTGGAGAGTTCCCCTCTCA-3' and a reverse primer 5' AGGCCGCGCTTGAATTC-3' (Genbank Accession No NM 013159) and rat glyceraldehydes-3-phosphate dehydrogenase (GAPDH) used as an internal control, had a forward primer 5'-CCT GGA GAA ACC TGC CAA GTA T-
3' and a reverse primer 5'-AGC CCA GGA TGC CCT TTA GT-3' (Genbank Accession No. NM 017008).

Quantification of IDE protein expression by western blot The plexus tissues or Z310 cells were homogenized (1:10, $\mathrm{wt} / \mathrm{vol}$ ) on ice in a buffer containing $20 \mathrm{mM}$ Tris ( $\mathrm{pH} 7.5$ ), $5 \mathrm{mM}$ EGTA, 1\% TritonX-100, 0.1\% SDS, $50 \mu \mathrm{M}$ phenylmethylsulphonylfluoride (PMSF), 15 mM 2-mercaptoethanol and a protease inhibitor cocktail containing $500 \mu \mathrm{M}$ 4-(2-Aminoethyl) benzenesulfonyl fluoride hydrochloride (AEBSF), $150 \mathrm{nM}$ aprotinin, $1 \mu \mathrm{M}$ E-64, $0.5 \mathrm{mM}$ EDTA, $1 \mu \mathrm{M}$ leupeptin (Calbiochem). Samples were sonicated using a Model 500 Sonic Dismembrator (Fisher Scientific) at duty cycle $20 \%$ and output 4-6 for 30 pulses. Following centrifugation at $10,000 \mathrm{~g}$ at $4^{\circ} \mathrm{C}$ for $10 \mathrm{~min}$, aliquots of supernatants were assayed for protein concentrations by the Bradford method. A volume of protein extract (40 $\mu \mathrm{g}$ of protein) was mixed with an equal volume of $2 \times$ sample buffer (0.35 M Tris-Cl, 10\% SDS, 30\% glycerol, $0.6 \mathrm{M} \mathrm{DTT}$, and $0.012 \%$ bromophenol blue), loaded onto a 10\% SDS-polyacrylamide gel, electrophoresed, and then transferred to a PVDF membrane. The membrane was blocked with 5\% dry milk in TBST (trisbuffered saline) at room temperature for $1 \mathrm{~h}$ and immunoblotted with an antibody directly against IDE (1:250). The membrane was stained with a horse-radish peroxidase (HRP)-conjugated goat anti-mouse IgG antibody (1:5000) at room temperature for $1 \mathrm{~h}$ and developed using ECL reagent. The exposure time varied from $30 \mathrm{sec}$ to several min depending on the signal strength. $\beta$-actin (42 kD) (1:2000) was used as a loading control; the corresponding secondary antibody $(1: 2000)$ for $\beta$-actin was HRP-conjugated goat anti-mouse IgG. All band intensities were quantified using Scion Image software (Frederick, USA).

\section{Determination of Pb-induced cellular toxicity in Z3 10 cells}

To determine the $\mathrm{Pb}$ concentration at which it altered $\mathrm{A} \beta$ metabolism in the CP in the absence of nonspecific cytotoxicity, three general cytotoxicity assays were conducted including the MTT cell viability assay, cell membrane permeability assessment (lactate dehydrogenase or LDH assay), and cellular oxidative stress estimation (superoxide dismutase or SOD assay). The MTT assay was performed by culturing Z310 cells at a density of 15,000 cells/well in a 96 well plate for 2-3 days until they reached $70 \%$ confluence. The medium was then replaced with fresh medium containing different concentrations of $\mathrm{Pb}$ as Pb-acetate $(0,1,5,10,50,100 \mu \mathrm{M})$. The cells were incubated for an additional $24 \mathrm{~h}$, followed by adding an aliquot of MTT stock solution ( $2 \mathrm{mg} / \mathrm{mL}$ in PBS) to each well. The absorbance of the converted dye was measured at a wavelength of $570 \mathrm{~nm}$. To determine the LDH activity, Z310 cells were treated as described above and LDH released into the culture medium was determined using 
the assay kit according to manufacturer's protocol. Finally, to determine oxidative stress, the cells were exposed to $\mathrm{Pb}$ $(10 \mu \mathrm{M})$ for $24 \mathrm{~h}$ and SOD activity was determined according to the instructions in the assay kit.

\section{Statistical analysis}

Statistical analyses were carried out by a one-way ANOVA with post hoc comparisons using the Dunnett's test or paired t-tests (Kaleidagraph 3.6). All data are expressed as mean \pm SD. Differences between two means were considered significant when the $p$ value was equal or less than 0.05 .

\section{Results}

Subcellular localization of IDE in choroid plexus tissues, choroidal epithelial Z3 IO cells and the effect of Pb

Immunostaining of normal rat lateral ventricle CP tissues revealed a distinct staining of IDE in the choroidal epithelia (Fig. 1). The IDE staining was primarily present in the cytosol towards the apical membrane including microvilli. There was very little staining in the cytosol towards the basement membrane facing the blood side (Fig. 1A). Acute in vivo exposure to $\mathrm{Pb}$ did not alter the subcellular localization of IDE, nor did it seem to affect the intensity of IDE staining (Fig. 1B). As expected, there was no staining in the negative control, which was the group treated in
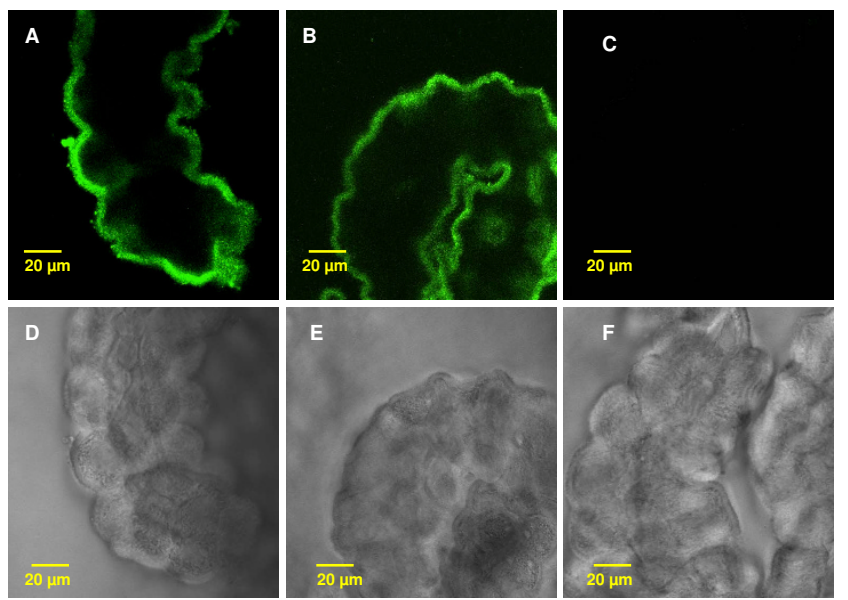

\section{Figure I}

Confocal immunofluorescence images showing intracellular location of IDE in rat choroid plexus tissue following in vivo acute $\mathbf{P b}$ exposure. $\mathrm{A}$ : The plexus tissues from a control rat. The IDE signals were present near the apical membrane of the epithelia, facing the CSF. B: Rats received a single ip injection of $27 \mathrm{mg} \mathrm{Pb} / \mathrm{kg}$. Twenty-four hours post exposure, there was no apparent sub-cellular relocalization of IDE following $\mathrm{Pb}$ exposure. $\mathrm{C}$ : Negative control without primary antibody. D, E, F: Transmission microscopy images. Note: The tissues in rats exposed to $\mathrm{Pb}(\mathrm{E})$ did not exhibit morphological alterations compared with controls (D). The images are representative of experiments run in triplicate. the absence of primary antibody (Fig. 1C). Noticeably, the corresponding transmission images revealed a normal morphology of the $\mathrm{CP}$ tissues following acute in vivo $\mathrm{Pb}$ exposure (Fig. 1D, E).

The IDE staining was also detected in choroidal epithelial Z310 cells with fluorescent signals evenly distributed in the cytosol (Fig. 2A). Since these cells lack polarity, no particular directional subcellular distribution of IDE was expected. Treatment with $\mathrm{Pb}(10 \mu \mathrm{M})$ for 24 or $48 \mathrm{~h}$ did not change either the localization or intensity of IDE staining in these cells (Fig. 2B, C). Transmission images revealed a normal morphology of $\mathrm{Z} 310$ cells (Fig. 2D, E, F).

\section{Acute $\mathrm{Pb}$ exposure decreases IDE activity in choroidal epithelial Z3 I 0 cells}

Prior to analyzing the IDE activity, it was necessary to ensure that the concentrations of $\mathrm{Pb}$ used in this study did not cause any direct cytotoxicity to the cells. The MTT, LDH and SOD assays were conducted for this purpose. The MTT assay with $\mathrm{Pb}$ concentration ranging between 0 $150 \mu \mathrm{M}$ revealed $95 \%$ viability at $10 \mu \mathrm{M} \mathrm{Pb}$ compared to controls. The LDH assays revealed that a concentration of $\mathrm{Pb}$ at or below $10 \mu \mathrm{M}$ had no significant effect on $\mathrm{LDH}$ release. Furthermore, results from the SOD assay did not show any significant oxidative stress when the cells were exposed to $\mathrm{Pb}$ at $10 \mu \mathrm{M}$. According to these findings,
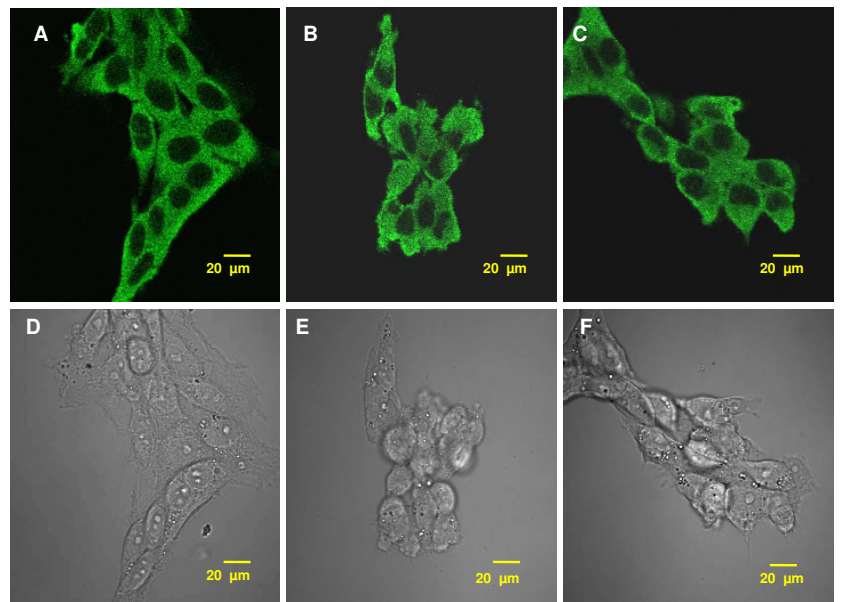

Figure 2

Confocal immunofluorescence images showing intracellular expression of IDE in rat choroidal epithelial Z3 I 0 cells following $\mathbf{P b}(10 \mu \mathrm{M})$ exposure. A: $\mathrm{Z} 3$ I 0 cells from untreated, control group. B: Z3 10 cells exposed to $\mathrm{Pb}$ for 24 h. C: Z3 10 cells exposed to $\mathrm{Pb}$ for $48 \mathrm{~h}$. No apparent subcellular re-localization of IDE was observed following $\mathrm{Pb}$ exposure in any of these groups. Transmission microscopy images indicate that the $\mathrm{Pb}$ treated cells $(\mathrm{E}, \mathrm{F})$ did not exhibit any morphological alterations compared to controls (D). The images are representative of experiments run in triplicate. 
together with previously published data from this group [37], a concentration of $10 \mu \mathrm{M} \mathrm{Pb}$ was selected for the following studies.

For the IDE activity study, NEM, an effective IDE inhibitor, was used as a positive control in the presence or absence of $\mathrm{Pb}$ exposure. Cells exposed to $\mathrm{Pb}$ for $24 \mathrm{~h}$ in the absence of NEM (Pb+, NEM-) showed a significant decrease of $17.6 \%$ in their IDE activity $(p<0.05)$ compared to untreated controls (Pb-, NEM-) (Fig. 3). Treatment with NEM alone $(10 \mu \mathrm{M})(\mathrm{Pb}-, \mathrm{NEM}+)$ resulted in a $17.5 \%$ decrease in the IDE activity $(p<0.05)$ and was comparable to the group treated with $\mathrm{Pb}$ in the absence of the inhibitor $(\mathrm{Pb}+, \mathrm{NEM}-)$. When the cells were exposed to a combination of $\mathrm{Pb}$ and NEM (NEM+, $\mathrm{Pb}+)$, the IDE activity was reduced by a significant $29.3 \%(p<0.001)$ relative to untreated controls (NEM-, Pb-), by $11.7 \%(p<$ $0.05)$ relative to the cells exposed to $\mathrm{Pb}$ alone $(\mathrm{Pb}+, \mathrm{NEM}-$ ) , and by $11.8 \%(p<0.05)$ relative to the NEM alone group $(\mathrm{Pb}-, \mathrm{NEM}+)$. NEM did not cause any significant cell death at the concentrations used, as determined by the MTT assay. These results suggested that exposure to $\mathrm{Pb}(10$ $\mu \mathrm{M})$ results in a decrease in IDE activity; the effect of $\mathrm{Pb}$ on the enzymatic activity of IDE was exacerbated in the presence of IDE inhibitor, NEM.

\section{Inhibition of IDE activity by $\mathrm{Pb}$ increases intracellular $\mathrm{A} \beta$ accumulation}

To determine if the inhibition of IDE activity led to cellular accumulation of $A \beta, Z 310$ cells were incubated with $A \beta$

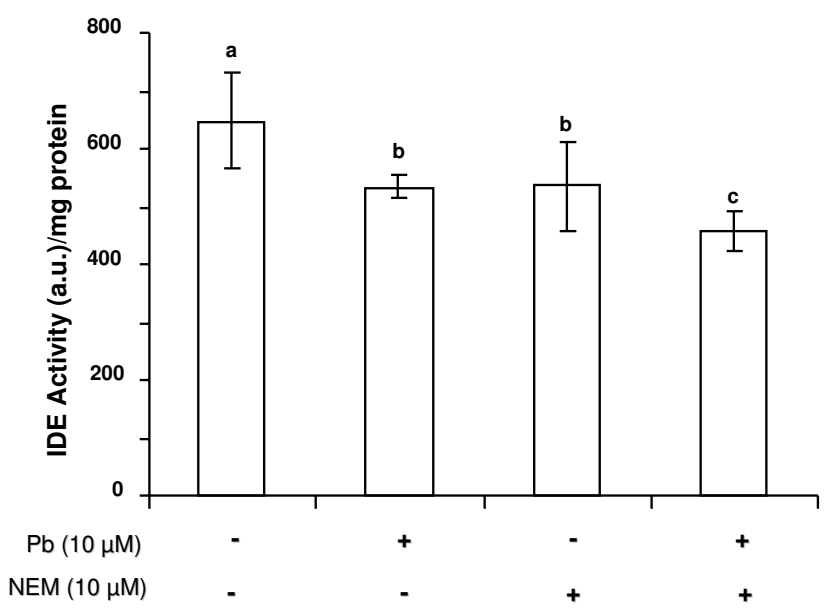

Figure 3

IDE activity following $\mathbf{P b}$ exposure (10 $\mu \mathrm{M}, 24 \mathrm{~h})$ in rat choroidal epithelial $\mathrm{Z3} I 0$ cells in the presence (+) or absence (-) of IDE inhibitor, NEM ( $10 \mu \mathrm{M})$. Data

represent mean $\pm S D, n=6-8$ wells per group. Bars with different superscripts are significantly different from one another, $p<0.05$.
$(2 \mu \mathrm{M})$ following treatment with $\mathrm{Pb}$ and/or NEM. Analysis using a one way ANOVA revealed an overall significant difference between the groups ( $p<0.01$, Fig. 4$)$. The cells treated with $\mathrm{Pb}$ alone $(\mathrm{Pb}+, \mathrm{NEM}-)$ showed a relatively small ( 1.5 fold), yet statistically significant increase in intracellular $\mathrm{A} \beta$ levels compared to untreated controls ( $p$ $<0.05)$. Treatment with NEM alone ( $\mathrm{Pb}-, \mathrm{NEM}+$ ) resulted in a 7 fold increase in intracellular $A \beta$ concentrations compared to untreated controls $(p<0.01)$.

When both $\mathrm{Pb}$ and NEM $(\mathrm{Pb}+, \mathrm{NEM}+)$ were added to the culture system, the intracellular $A \beta$ levels were increased by nearly 12 fold $(p<0.01)$. This finding supports a synergistic effect between $\mathrm{Pb}$ and NEM; both may possibly alter the IDE activity and subsequently decrease $A \beta$ metabolism in the CP.

\section{Pb exposure did not alter the expression of IDE $m R N A$ and protein in CP tissues or choroidal Z310 cells}

The effect of $\mathrm{Pb}$ on IDE function could also be due to the altered expression of IDE. To test this hypothesis, rats were exposed to $\mathrm{Pb}$ by a single injection of $27 \mathrm{mg} \mathrm{Pb} / \mathrm{kg}$ i.p. for $24 \mathrm{~h}$. No significant difference was observed either in the IDE mRNA expression level as quantified by real time RTPCR (Fig. 5A), or in the protein expression level as determined by western blot analysis (Fig. 5B, C). In addition, there was an absence of a significant alteration in mRNA (Fig. 6A) and protein (Fig. 6B, C) in choroidal Z310 cells treated with $10 \mu \mathrm{M} \mathrm{Pb}$ for 24 or $48 \mathrm{~h}$.

\section{Discussion}

Our data clearly demonstrate that (i) IDE is located towards the apical membrane in $\mathrm{CP}$ tissues and the distri-

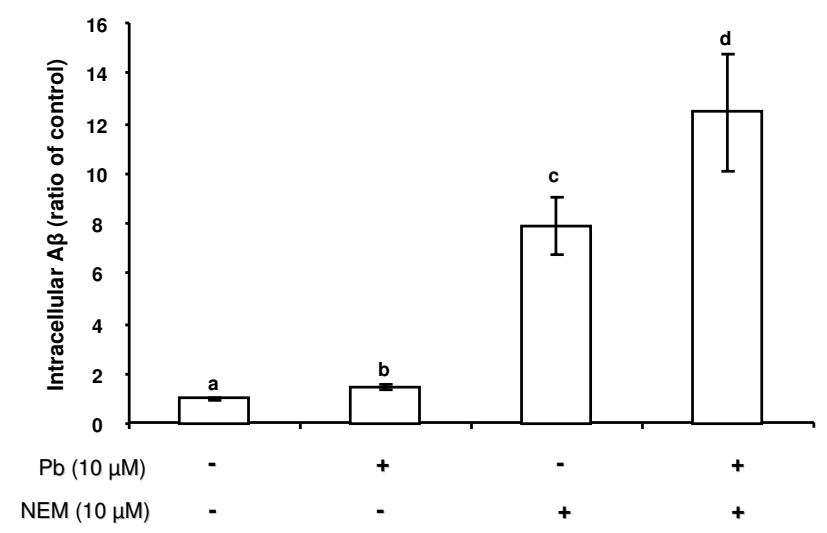

Figure 4

Quantification of intracellular A $\beta$ levels by ELISA in Z3 I 0 cells following $\mathrm{Pb}(\mathrm{I} 0 \mu \mathrm{M}, 24 \mathrm{~h})$ exposure in the presence (+) or absence (-) of NEM (1 $0 \mu \mathrm{M})$. Data represent mean $\pm S D, n=6-8$ wells per group. Bars with different superscripts are significantly different from one another, $p<0.05$. 

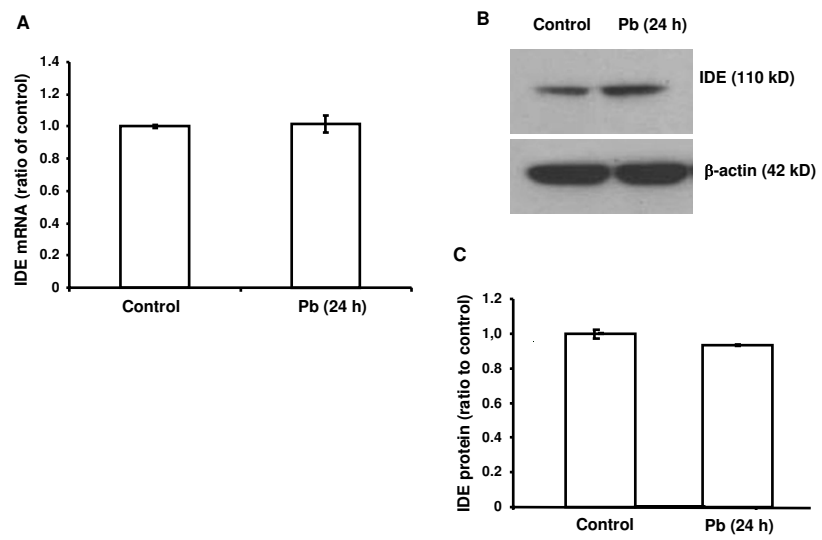

\section{Figure 5}

IDE mRNA and protein expression following Pb exposure in rat CP tissue. Rats received ip injection of either $\mathrm{Na}$ acetate (control) or $\mathrm{Pb}$ acetate $(27 \mathrm{mg} \mathrm{Pb} / \mathrm{kg})$ and tissues were analyzed $24 \mathrm{~h}$ after $\mathrm{Pb}$ exposure. $\mathrm{A}$ : IDE mRNA expression. No significant difference was observed between $\mathrm{Pb}$-exposed and control groups as indicated by the ratio of IDE/GAPDH. B: Representative western blots of IDE protein expression in controls and $\mathrm{Pb}$-treated rats. $\mathrm{C}$ : IDE expression estimated from the corresponding band densities in (B) and normalized to those of $\beta$-actin indicating. No significant difference was observed in IDE protein expression between $\mathrm{Pb}$-treated and control rats. Data represent mean $\pm \mathrm{SD}, \mathrm{n}=$ 4. The data are representative of triplicate experiments.

bution does not appear to be altered by $\mathrm{Pb}$ exposure; (ii) $\mathrm{Pb}$ exposure results in a significant decrease in IDE activity; (iii) the decrease in IDE activity by $\mathrm{Pb}$ may lead to an accumulation of $A \beta$ in the $\mathrm{CP}$ possibly due to a reduced metabolic clearance at the BCB; and (iv) Pb exposure does not alter the mRNA or protein expression of IDE.

The observation that the subcellular location of IDE was concentrated towards the apical membrane has significant implications. Earlier studies in our laboratory have demonstrated that the direction of $\mathrm{A} \beta$ transport by the $\mathrm{CP}$ is predominantly from the CSF to the blood [16]. The presence of IDE immediately beneath the apical membrane would allow this enzyme to effectively metabolize the $A \beta$ molecules entering from the CSF. Hence, the immediate breakdown of A $\beta$ by IDE may facilitate the ability of the $\mathrm{CP}$ to continuously attract extracellular $A \beta$; this may also explain the large capacity of the $\mathrm{CP}$ to take up $\mathrm{A} \beta$ from the CSF [16].

Recent studies in our laboratory have shown that exposure to $\mathrm{Pb}$ results in the accumulation of intracellular $\mathrm{A} \beta$ [15]; the study employed the same $\mathrm{Pb}$ exposure dose regimen as used in the current experiment. Under such a dose regimen, the $\mathrm{Pb}$ concentrations in blood and CSF reach
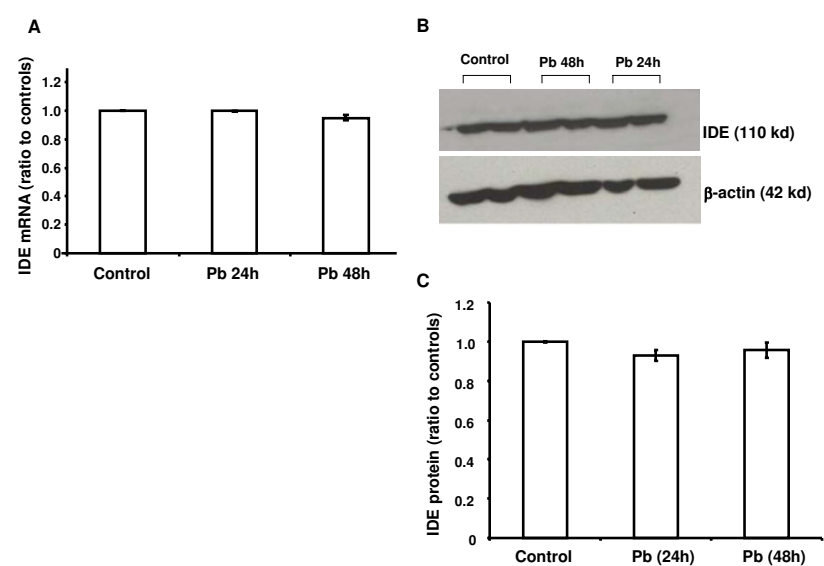

\begin{abstract}
Figure 6
IDE mRNA and protein expression in Z3 10 cells following $\mathbf{P b}$ exposure. $\mathrm{Z} 310$ cells were treated with $10 \mu \mathrm{M}$ $\mathrm{Pb}$ for $24 \mathrm{~h}$ or $48 \mathrm{~h}$. A: IDE mRNA expression. No significant difference was observed in the mRNA expression between the $\mathrm{Pb}$-exposed and control groups. $\mathrm{B}$ : Representative western blots of IDE protein expression in controls and cells treated with $\mathrm{Pb}(10 \mu \mathrm{M})$ for 24 and $48 \mathrm{~h}$. C: IDE expression estimated from the corresponding band densities (B) and normalized to those of $\beta$-actin. No significant difference in IDE protein expression was found between $\mathrm{Pb}$-treated and control cells. Data represent mean $\pm S D, n=3$. The data are representative of triplicate experiments.
\end{abstract}

$400 \mu \mathrm{g} / \mathrm{dL}$ and $32 \mu \mathrm{g} / \mathrm{dL}$, respectively; the $\mathrm{Pb}$ concentration in the CP is about $22 \mu \mathrm{g} / \mathrm{g}$ of tissue, nearly 57 fold greater than $\mathrm{Pb}$ in brain cortex [13]. Recently published data by this group also demonstrate that incubating Z310 cells with 1-10 $\mu \mathrm{M}$ of $\mathrm{Pb}$ (about 20.7-207 $\mu \mathrm{g} / \mathrm{dL}$ in the culture medium) produced a dose-time dependent increase in cellular accumulation of $A \beta$ while not causing significant cell damage (i.e., normal cell viability, normal LDH and normal SOD) [15]. This basic finding could be explained at least in part by $\mathrm{Pb}$ facilitating the uptake of $\mathrm{A} \beta$ by the $\mathrm{CP}$ and/or $\mathrm{Pb}$ inhibiting $\mathrm{A} \beta$ breakdown in the $\mathrm{CP}$. The data in the current study indicated that $\mathrm{Pb}$ may directly act on IDE by inhibiting its activity rather than altering its gene or protein expression.

Results from this study indicated that while $\mathrm{Pb}$ exposure caused a 1.5 fold increase in $A \beta$, the group treated with NEM alone caused a 7 fold increase in $A \beta$. This may be, in part, due to a non-IDE-related effect of NEM, since NEM action involves a general covalent binding to cysteine residues. One strategy for future studies would be to knockdown IDE using short interference RNA and to more specifically determine the contribution of IDE. Another approach would be to up-regulate IDE in these cells and analyze $A \beta$ accumulation in the presence or absence of $\mathrm{Pb}$ exposure. We would also like to point out that due to a 
small tissue mass, we were unable to assess the IDE activity in the $\mathrm{CP}$ tissue following in vivo $\mathrm{Pb}$ exposure. As a future direction, it would be of interest to know how our in vitro studies correlate with in vivo IDE activity in the CP.

The current study raises several interesting questions. By what potential mechanism does $\mathrm{Pb}$ exert its effects on IDE? Extensive literature suggests that $\mathrm{Pb}$ is capable of binding to $\mathrm{Zn}$ finger proteins and subsequently altering their function, specifically at the sp1 binding domain [3840]. IDE activity is shown to be metal or thiol-dependent $[19,41]$ and structurally comprises a $\mathrm{Zn}$ binding motif, as well as an inverted metalloprotease motif named HxxEH [24]. These, along with several cysteine-histidine clusters, allow the enzyme to bind to substrates such as $A \beta$ and assist in its cleavage. At the same time, IDE could potentially interact with DNA to regulate transcriptional events [42]. $\mathrm{Pb}$, being a divalent metal like $\mathrm{Zn}$ may compete with and replace $\mathrm{Zn}$ in the $\mathrm{Zn}$ finger binding domain. At the transcriptional regulatory level, this binding can alter the upstream signaling pathways that are important to cell function [43-45]. Since the structure of IDE contains a $\mathrm{Zn}$ motif, we speculate that $\mathrm{Pb}$ may directly bind to the $\mathrm{Zn}$ finger binding domain and inhibit IDE activity. However, this is a preliminary speculation and further studies are warranted to explore this mechanism.

Upstream of binding to the $\mathrm{Zn}$ finger, $\mathrm{Pb}$ might also influence the protein kinase C (PKC) pathway. Studies in literature suggest that IDE activity is decreased by an energydependent ATP mechanism [46]. PKC is known to phosphorylate amino acids by ATP-driven reactions and has been implicated in $\mathrm{Pb}$ toxicity in both animals and in humans [47-51]. Specifically, findings reveal that exposure to $\mathrm{Pb}$ results in PKC- mediated impairments in hippocampal development, the brain area that is primarily affected in $\mathrm{AD}[40]$. Since $\mathrm{Pb}$ has shown to activate several isoforms of PKC in the CP [52], it would be of interest to explore whether and how activation of PKC may relate to alterations in IDE activity.

Another question is how much of a role does IDE play in Pb-mediated accumulation of A $\alpha$ ? We should point out that this study does not imply that IDE is the single most important factor in $A \beta$ regulation at the $B C B$. Other mechanisms, particularly receptor-mediated $A \beta$ uptake and clearance in the CP including the involvement of $A \alpha$ transporters such as low density lipoprotein receptor protein 1 (LRP1), receptor for advanced glycosylation end products (RAGE) and p-glycoprotein must also be considered.

Finally, what is the consequence of $A \beta$ accumulation in the $\mathrm{CP}$ following $\mathrm{Pb}$ exposure? $\mathrm{A}$ build up of $\mathrm{A} \beta$ in the $\mathrm{CP}$ could either be a result of overproduction of $A \beta$ in the
CNS under the interference of $\mathrm{Pb}$, or maybe due to a compromised function of the $\mathrm{CP}$ in clearing $\mathrm{A} \beta$ from the CSF. Data from the current study indicate that $\mathrm{Pb}$ may alter the $\mathrm{A} \beta$ breakdown mechanism at a critical site in the brain that is often overlooked. A disruption in $A \beta$ clearance, in turn, might lead to elevated $A \beta$ accumulation in the brain's internal milieu. Although this study provides some evidence for an IDE-mediated metabolic clearance, further studies are warranted to explore this mechanism indepth.

\section{Conclusion}

In summary, our results provide evidence that $\mathrm{Pb}$ exposure increases $\mathrm{A} \beta$ accumulation at the $\mathrm{BCB}$ at least in part, by altering the activity of IDE and thereby potentially decreasing the metabolic clearance of $\mathrm{A} \beta$. In addition, we provide evidence that IDE in the CP is localized towards the apical membrane, which is consistent with the large capacity of the CP to take up A $\beta$ from the CSF. Finally, our study suggests that $\mathrm{Pb}$ is a potential environmental trigger in the dysregulation of $A \beta$ homeostasis, and may subsequently contribute to the etiology of $\mathrm{AD}$.

\section{Abbreviations}

$\mathrm{A} \beta$ : beta-amyloid; $\mathrm{AD}$ : Alzheimer's disease; BCB: bloodCSF barrier; CP: choroid plexus; CSF: cerebrospinal fluid; ELISA: enzyme-linked immunosorbent assay; IDE: insulin degrading enzyme; LDH: lactate dehydrogenase; MRI: magnetic resonance imaging; MTT: methylthiazolyldiphenyl-tetrazolium bromide; NEM: n-ethylmaleimide; $\mathrm{Pb}$ : lead; PKC: protein kinase C; RT-PCR: reverse transcription polymerase chain reaction; SOD: superoxide dismutase.

\section{Competing interests}

The authors declare that they have no competing interests.

\section{Authors' contributions}

$\mathrm{MB}$ participated in designing the study, performing the experiments, analyzing and interpreting the data and drafting the manuscript. YZ participated in designing the study, assisted in carrying out the experiments and analyzing the data. WZ (senior author) participated in designing the study, interpreting the data and revising the manuscript. All authors have read and approved the final manuscript.

\section{Acknowledgements}

The authors would like to thank Dr. Li Li, Andrew Monnot and Dr. Wendy Jiang for their technical assistance with the project. This work was supported in part by $\mathrm{NIH} / \mathrm{National}$ Institute of Environmental Health Sciences Grants Numbers ESO08I46 and ESOI 7055.

\section{References}

I. Bertram L, Tanzi RE: Alzheimer's disease: One disorder, too many genes? Hum Mol Gen 2004, I3:R I35-R I4I.

2. Shih RA, Hu H, Weisskopf MG, Schwartz BS: Cumulative lead dose and cognitive function in adults: a review of studies that 
measured both blood lead and bone lead. Environ Health Perspect 2007, I I 5:483-492.

3. Stewart WF, Schwartz BS, Davatzikos C, Shen D, Liu D, Wu X, Todd $A C$, Shi W, Bassett $S$, Youssem D: Past adult lead exposure is linked to neurodegeneration measured by brain MRI. Neurology 2006, 66: I476-I 484.

4. Niklowitz WJ, Mandybur TI: Neurofibrillary changes following childhood lead encephalopathy. J Neuropathol Exp Neurol 1975, 34:445-455.

5. Jiang YM, Long LL, Zhu XY, Zheng H, Fu X, Ou SY, Wei DL, Zhou $H L$, Zheng W: Evidence for altered hippocampal volume and brain metabolites in workers occupationally exposed to lead: A study by magnetic resonance imaging and $1 \mathrm{H}$ magnetic resonance spectroscopy. Toxicol Lett 2008, I 8 I: I I 8-125.

6. Stewart WF, Schwartz BS, Simon D, Bolla KI, Todd AC, Links J: Neurobehavioral function and tibial and chelatable lead levels in 543 former organolead manufacturing workers. Neurology 1999, 52:1610-1617.

7. Stewart WF, Schwartz BS, Simon D, Kelsey K, Todd AC: ApoE genotype, past adult lead exposure, and neurobehavioral function. Environ Health Perspect 2002, I I 0:50I-505.

8. Basha MR, Wei W, Bakheet SA, Benitez N, Siddiqi HK, Ge YW, Lahiri $\mathrm{DK}$, Zawia NH: The fetal-basis of amyloidogenesis: exposure to lead and latent over-expression of amyloid precursor protein beta-amyloid in the aging brain. J Neurosci 2005, 25:823-829.

9. Haraguchi $\mathrm{T}$, Ishizu H, Takehisa $\mathrm{Y}$, Kawai K, Yokota O, Terada S, Tsuchiya K, Ikeda K, Morita K, Horike T, Kira S, Kuroda S: Lead content of brain tissue in diffuse neurofibrillary tangles with calcification (DNTC): the possibility of lead neurotoxicity. Neuroreport 2001, 21:3887-3890.

10. Wu J, Basha MR, Brock B, Cox DP, Cardozo-Pelaez F, McPherson CA, Harry J, Rice DC, Maloney B, Chen D, Lahiri DK, Zawia NH: Alzheimer's disease (AD)-like pathology in aged monkeys after infantile exposure to environmental metal lead (Pb): evidence for a developmental origin and environmental link for AD. I Neurosci 2008, 28:3-9.

II. Friedheim E, Corvi C, Graziano J, Donnelli T, Breslin D: Choroid plexus as protective sink for heavy metals? Lancet 1983 8331:981-982.

12. Manton WI, Kirkpatrick JB, Cook JD: Does the choroid plexus really protect the brain from lead? Lancet 1984, 8398:35I.

13. Zheng W, Perry DF, Nelson DL, Aposhian HV: Protection of cerebrospinal fluid against toxic metals by the choroid plexus. FASEB ] 1991, 5:2188-2193.

14. Zheng W, Shen H, Blaner WS, Zhao Q, Ren X, Graziano JH: Chronic lead exposure alters transthyretin concentration in rat cerebrospinal fluid: the role of the choroid plexus. Toxicol Appl Pharmacol 1996, 139:445-450.

15. Behl M, Zhang Y, Monnot AD, liang W, Zheng W: Increased $\beta$-amyloid levels in the choroid plexus following lead exposure and the involvement of low density lipoprotein receptor proteinI. Toxicol Appl Pharmacol 2009 in press.

16. Crossgrove JS, Li GJ, Zheng W: The choroid plexus removes beta-amyloid from the cerebrospinal fluid. Exp Biol Med 2005 230:77।-776.

17. Kurochkin IV: Insulin-degrading enzyme: embarking on amyloid destruction. Trends Biochem Sci 200I, 26:42I-425.

18. Kurochkin IV, Goto S: Alzheimer's $\beta$-amyloid peptide specifically interacts with and is degraded by insulin degrading enzyme. FEBS Lett 1994, 345:33-37.

19. Mc Dermott JR, Gibson AM: Degradation of Alzheimer's $\beta$-amyloid protein by human and rat brain peptidases: involvement of insulin-degrading enzyme. Neurochem Res 1997, 22:49-56.

20. Pérez A, Morelli L, Cresto JC, Castaño EM: Degradation of soluble amyloid beta-peptides I-40, I-42, and the Dutch variant I$40 \mathrm{Q}$ by insulin degrading enzyme from Alzheimer disease and control brains. Neurochem Res 2000, 25:247-55.

21. Qiu WQ, Walsh DM, Ye Z, Vekrellis K, Zhang J, Podlisny MB, Rosner MR, Safavi A, Hersh LB, Selkoe DJ: Insulin-degrading enzyme regulates extracellular levels of amyloid beta protein by degradation. I Biol Chem 1998, 273:32730-32738.

22. Dische FE, Wernstedt C, Westermark GT, Westermark P, Pepys MB, Rennie JA, Gilbey SG, Watkins PJ: Insulin as an amyloid fibril protein at sites of repeated insulin injections in a diabetic patient. Diabetologia 1988, 31:158-161.
23. Stentz FB, Kitabchi AE, Schilling JW, Schronk LR, Seyer JM: Identification of insulin intermediates and sites of cleavage of native insulin by insulin protease from human fibroblasts. J Biol Chem 1989, 5:20275-20282

24. Becker $A B$, Roth RA: Insulysin and pitrilysin: insulin degrading enzyme of mammals and bacteria. Meth Enzymol 1995, 248:693-703.

25. Leissring MA, Farris $W$, Chang AY, Walsh DM, Wu X, Sun $X$, Frosch MP, Selkoe DJ: Enhanced proteolysis of $\beta$-amyloid in APP transgenic mice prevents plaque formation, secondary pathology, and premature death. Neuron 2003, 40:1087-1093.

26. Qiu WQ, Ye Z, Kholodenko D, Seubert P, Selkoe DJ: Degradation of amyloid $\beta$-protein by a metalloprotease secreted by microglia and other neural and non-neural cells. J Biol Chem 1997, 272:664I-6646.

27. Kim M, Hersh LB, Leissring MA, Ingelsson M, Matsui T, Farris W, Lu A, Hyman BT, Selkoe DJ, Bertram L, Tanzi RE: Decreased catalytic activity of the insulin-degrading enzyme in chromosome 10 linked Alzheimer's disease families. J Biol Chem 2007, 282:7825-7832

28. Ertekin-Taner N, Graff-Radford N, Younkin LH, Eckman C, Baker M, Adamson J, Ronald J, Blangero J, Hutton M, Younkin SG: Linkage of plasma $A \beta 42$ to a quantitative locus on chromosome 10 in late-onset Alzheimer's disease pedigrees. Science 2000, 290:2303-2304.

29. Farris W, Mansourian S, Chang Y, Lindsley L, Eckman EA, Frosch MP, Eckman CB, Tanzi RE, Selkoe DJ, Guenette S: Insulin-degrading enzyme regulates the levels of insulin, amyloid $\beta$-protein, and the $\beta$-amyloid precursor protein intracellular domain in vivo. Proc Natl Acad Sci 2003, 100:4 I62-4I67.

30. Myers A, Holmans P, Marshall H, Kwon J, Meyer D, Ramic D, Shears S, Booth J, DeVrieze FW, Crook R, Hamshere M, Abraham R, Tunstall N, Rice F, Carty S, Lillystone S, Kehoe P, Rudrasingham V, Jones L, Lovestone S, Perez-Tur J, Williams J, Owen MJ, Hardy J, Goate AM: Susceptibility locus for Alzheimer's disease on chromosome 10. Science 2000, 290:2304-2305.

31. Zhao W, Chen H, Xu H, Moore E, Meiri N, Quon MJ, Alkon DL: Brain insulin receptors and spatial memory correlated changes in gene expression, tyrosine phosphorylation, and signaling molecules in the hippocampus of water maze trained rats. J Biol Chem 1999, 274:34893-34902.

32. Miller BC, Eckman EA, Sambamurti K, Dobbs N, Chow KM, Eckman CB, Hersh LB, Thiele DL: Amyloid- $\beta$ peptide levels in brain are inversely correlated with insulysin activity levels in vivo. Proc Natl Acad Sci 2003, 100:6221-6226.

33. Zhao Z, Xiang Z, Haroutunian V, Buxbaum JD, Stetka B, Pasinetti GM: Insulin-degrading enzyme activity selectively decreases in the hippocampal formation of cases at high risk to develop Alzheimer's disease. Neurobiol Aging 2007, 28:824-830.

34. Crossgrove JS, Smith EL, Zheng W: Macromolecules involved in production and metabolism of beta-amyloid at the brain barriers. Brain Res 2007, 138:187-195.

35. Zheng W, Zhao Q: Establishment and characterization of an immortalized Z3 I 0 choroidal epithelial cell line from murine choroid plexus. Brain Res 2002, 958:37I-380

36. Walker N]: Real -time and quantitative PCR: applications to mechanism-based toxicology. J Biochem Mol Toxicol 200I, I5:121-127.

37. Shi LZ, Zheng W: Early lead exposure increases the leakage of the blood-cerebrospinal fluid barrier, in vitro. Hum Exp Toxicol 2007, 26:159-167.

38. Atkins DS, Basha MR, Zawia NH: Intracellular signaling pathways involved in mediating the effects of lead on the transcription factor Sp I. Int I Dev Neurosci 2003, 2 I:235-244.

39. Hanas JS, Rodgers JS, Bantle JA, Cheng Y: Lead inhibition of DNAbinding mechanism of Cys2-His2 zinc finger proteins. Mol Pharmacol 1999, 56:982-988.

40. Zawia NH, Crumpton T, Brydie M, Reddy GR, Razmi Afshari M: Disruption of the zinc finger domain: a common target that underlies many of the effects of lead. Neurotoxicology 2000, 2I:I-II.

4I. Fery MN, Garcia-Ordon RD, Logan TP, Selkoe DJ, Li L: Molecular basis for the thiol sensitivity of insulin-degrading enzyme. Proc Natl Acad Sci 2008, 105:9582-9587.

42. Radulescu RT: Insulin Receptor $\alpha$-subunit: A Putative Gene Regulatory Molecule. Med Hypotheses 1995, 45: I07-III. 
43. Basha MR, Wei W, Brydie M, Razmiafshari M, Zawia NH: Leadinduced developmental perturbations in hippocampal SpI DNA-binding are prevented by zinc supplementation: in vivo evidence for $\mathbf{P b}$ and $\mathbf{Z n}$ competition. Int J Dev Neurosci 2003, 2I:I-12.

44. Zawia NH, Sharan R, Brydie M, Oyama T, Crumpton T: Sp I as a target site for metal-induced perturbations of transcriptional regulation of developmental brain gene expression. Dev Brain Res 1998, 107:291-298.

45. Zawia NH: Transcriptional involvement in neurotoxicity. Toxicol Appl Pharmacol 2003, 190:177-188.

46. Camberos MC, Pérez AA, Udrisar DP, Wanderley MI, Cresto IC: ATP Inhibits Insulin-Degrading Enzyme Activity. Exp Biol Med 200I, 226:334-34I.

47. Bressler JP, Goldstein GW: Mechanisms of lead neurotoxicity. Biochem Pharmacol 1991, 41:479-484.

48. Laterra J, Bressler JP, Indurti RR, Belloni-Olivi L, Goldstein GW: Inhibition of astroglia-induced endothelial differentiation by inorganic lead: a role for protein kinase C. Proc Natl Acad Sci 1992, 89: 10748-10752.

49. Long G], Rosen JF, Schanne FA: Lead activation of protein kinase $C$ from rat brain Determination of free calcium, lead, and zinc by I9F NMR. J Biol Chem 1994, 269:834-837.

50. Markovac J, Goldstein GW: Lead activates protein kinase $\mathbf{C}$ in immature rat brain microvessels. Toxicol Appl Pharmacol 1988, 96:14-23.

5I. Markovac J, Goldstein GW: Picomolar concentrations of lead stimulate brain protein kinase C. Nature 1988, 334:7I-73.

52. Zhao Q, Slavkovich $\mathrm{V}$, Zheng W: Lead exposure promotes translocation of protein kinase $C$ activities in rat choroid plexus in vitro, but not in vivo. Toxicol Appl Pharmacol 1998, 149:99-106.

Publish with Bio Med Central and every scientist can read your work free of charge

"BioMed Central will be the most significant development for disseminating the results of biomedical research in our lifetime. "

Sir Paul Nurse, Cancer Research UK

Your research papers will be:

- available free of charge to the entire biomedical community

- peer reviewed and published immediately upon acceptance

- cited in PubMed and archived on PubMed Central

- yours - you keep the copyright 